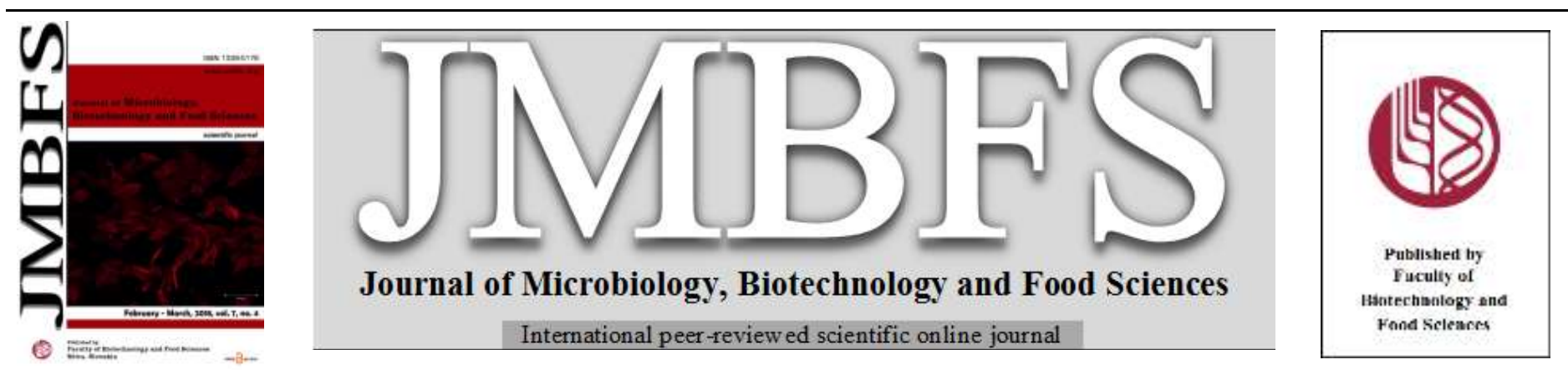

\title{
COMPARATIVE INDICATORS OF FATTY ACID COMPOSITION OF RAINBOW TROUT (ONCORHYNCHUS MYKISS WALBAUM, 1792) FROM VARIOUS AQUACULTURE FACILITIES IN MACEDONIA
}

\author{
Biljana Sivakova ${ }^{1}$, Dijana Blazhekovikj - Dimovska*²
}

Address(es): PhD Dijana Blazhekovikj - Dimovska,

${ }^{1}$ Food and Veterinary Agency of Republic of Macedonia.

${ }^{2}$ University „St. Kliment Ohridski“, Faculty of Biotechnical Sciences, Department of biotechnology, Partizanska b.b., 7000 Bitola, Macedonia.

*Corresponding author: dijanablazekovic@yahoo.com

doi: $10.15414 / j m b f s .2018 .7 .4 .395-398$

\section{ARTICLE INFO}

Received 10. 6. 2017

Revised 22. 9. 2017

Accepted 19. 10. 2017

Published 1. 2. 2018

Regular article

orten 2 acctss

\section{ABSTRACT}

The objective of this study was to make a comparative analysis of the fatty acid composition of the rainbow trout (Oncorhynchus mykiss Walbaum, 1792) with consumption size of 250-300 g, from two different aquaculture facilities - coldwater fishponds (fishpond A and fishpond B) in Macedonia, at different ambient conditions in the aquatic environment, and with the use of pelleted food from different manufacturers.

Considering the results of the fatty acid composition of the rainbow trout from the fishpond $\mathrm{A}$ and the fishpond $\mathrm{B}$, it can be concluded that the content of the saturated fatty acids (SFA) is higher in the fishpond B (20.303\%) compared to the fishpond A (16.155\%), while the content of the monounsaturated fatty acids (MUFA) and the polyunsaturated fatty acids (PUFA) is greater in the fishpond A (MUFA - 53.364\%; PUFA - 30.435\%) compared to the fishpond B (MUFA - 52.359\%; PUFA - 27.268\%).

Overall, by a comparative analysis of the qualitative properties of the rainbow trout from the both aquaculture facilities, the ambient conditions prevailing in the aquatic environment, and the used forage mixtures for feeding fish, it can be concluded that the both aquaculture facilities are producing fish with high nutritional quality in terms of the fatty acid composition.

Keywords: rainbow trout (Oncorhynchus mykiss Walbaum, 1792), fatty acid composition

\section{INTRODUCTION}

Freshwater and marine fish species are a good source of essential fatty acids (Özoğul et al., 2007). Variations in lipid and fatty acid compositions between and within fish species depend on many factors such as food availability, season, environmental temperature, geographic location, sex, diet and age, physical and chemical properties of water, rearing conditions, physical activity and nutritional habits of the fish (Gorgun and Akpinar 2007). Therefore, the fatty acid composition of fish absolutely differs from feeding conditions. According Jankowska et al. (2003) fatty acid composition is the major factor that determines the quality and flavor aspects of fish meat.

Oncorhynchus mykiss (Walbaum, 1792), commonly known as rainbow trout, inhabits cold headwaters, creeks, rivers and lakes. It is widely used in aquaculture in many countries because of its rapid growth and high market value due to its flesh quality (Sarma et al., 2013). The low fat content, the protein content of high biological value, and the content of a significant amount of essential fatty acids make the rainbow trout one of the most highly rated fish in the human diet. Fish oils contain n-3 polyunsaturated fatty acid (PUFA), particularly, eicosapentaenoic acid (EPA; C20:5 n3) and docosahexaenoic acid (DHA; C22:6 n3) (Aslan et al., 2007). The importance of the long-chain PUFA has gained attention due to the prevention of human coronary artery disease (Mozaffarian $\boldsymbol{e}$ al., 2005), improvement of retina and brain development (Crawford, 1993), reduce the risk of heart attacks and also decrease incidence of breast cancer, rheumatoid arthritis, multiple sclerosis, psoriasis and inflammation (Daviglus $\boldsymbol{e t}$ al., 1997).

The objective of this study was to make a comparative analysis of the fatty acid composition of the rainbow trout (Oncorhynchus mykiss Walbaum, 1792) with consumption size of 250-300 g, from two different aquaculture facilities coldwater fishponds (fishpond A and fishpond B) in Macedonia, at different ambient conditions in the aquatic environment, and with the use of pelleted food from different manufacturers.

\section{MATERIAL AND METHODS}

Examinations were performed on rainbow trout (Oncorhynchus mykiss Walbaum, 1792) with consumption size of 250-300 g from two aquaculture facilities coldwater fishponds (fishpond A and fishpond B) in Macedonia.

The fishpond A is located in Demir Hisar region (Macedonia) and it is supplied with water from the river Crna, spring Zheleznec. In this fishpond pelleted food Aller silver $(6 \mathrm{~mm})$ from manufacturer Aller aqua (Poland) is used, with following content (per specification): fish meal, wheat, fish oil, soy, hemoglobin powder, hydrolyzed protein, protein concentrates from sunflower and oil rape. Besides the main components, the food contains the following components (per specification): phosphate $(1 \%)$, calcium $(0.8 \%)$, sodium $(0.2 \%)$, vitamin A $(10,000$ ie/kg), vitamin D3 (1000 IE/ $/ \mathrm{kg})$, antioxidant E 324 ethoxyquin (100 $\mathrm{mg} / \mathrm{kg}$ ), trace elements E2 iodine ( $3 \mathrm{mg} / \mathrm{kg})$, E4 copper $(5 \mathrm{mg} / \mathrm{kg})$, E5 manganese $(12 \mathrm{mg} / \mathrm{kg})$, E6 zinc $(70 \mathrm{mg} / \mathrm{kg})$, and pigments Astaxanthin E161j $(50 \mathrm{mg} / \mathrm{kg})$ and Canthaxanthin E161g $(25 \mathrm{mg} / \mathrm{kg})$.

The average mass of rainbow trout samples from fishpond A was $285 \mathrm{~g}$, while the average length, $29 \mathrm{~cm}$.

The fishpond B is located near the city of Bitola (Macedonia) and it is supplied with water from the reservoir Strezhevo. In this fishpond pelleted food Troco prime $18(4.5 \mathrm{~mm})$ from manufacturer Coppens International (Netherlands) is used, with following content (per specification): fish meal, wheat, fish oil, soy, wheat gluten, hemoglobin powder and oil rape. Besides the main components, the food contains the following components (per specification): phosphorus $(0.96 \%)$, calcium $(1.6 \%)$, sodium $(0.3 \%)$, vitamin A $(10.000 \mathrm{ie} / \mathrm{kg})$, vitamin C $(150$ $\mathrm{mg} / \mathrm{kg})$, vitamin E $(200 \mathrm{mg} / \mathrm{kg})$, vitamin D3 (799 ie/ $/ \mathrm{kg})$, antioxidants E 324 ethoxyquin $(100 \mathrm{mg} / \mathrm{kg}$ ) and E321 butilied hidroksitulen $(40 \mathrm{mg} / \mathrm{kg})$, as well as trace elements E1 iron ( $75 \mathrm{mg} / \mathrm{kg})$, E2 iodine $(5 \mathrm{mg} / \mathrm{kg})$, E4 copper $(5 \mathrm{mg} / \mathrm{kg})$, E5 manganese $(20 \mathrm{mg} / \mathrm{kg})$ and E6 zinc $(80 \mathrm{mg} / \mathrm{kg})$.

The average mass of rainbow trout samples from fishpond B was $267 \mathrm{~g}$, while the average length, $27.2 \mathrm{~cm}$

During examinations, the following methods for determination of fatty acid composition in fish meat were used:

-Determination of fatty acid composition by gas chromatography - AOAC method 996.06 . 
Methods for physical - chemical properties of water in fish ponds that are used: -pH determination - ISO 1052:1994;

-Chloride determination - ISO 9297:1989;

-Spectrophotometric determination of nitrates - HACH DR 400 procedure

Method 8039;

-Spectrophotometric determination of iron - HACH DR 400 procedure Method 8365 ;

-Spectrophotometric determination of nitrites - HACH DR 400 procedure Method 8507;

-Turbidity determination of translucency - ISO 7027:1999;
-Spectrophotometric determination of ammonia - HACH DR 400 procedure Method 8038;

-Determination of chemical oxygen demand - Merck Method Spectroquant 1.18752.0001;

-Total nitrogen determination - Merck Method Spectroquant 1.14537.0001.

\section{RESULTS AND DISCUSSION}

Considering the results of the physical - chemical analysis of water in fishpond $\mathrm{A}$ and fishpond $\mathrm{B}$, we`ve obtained the following results (Table 1):

Table 1 Physical - chemical properties of water in fishpond A and fishpond B

\section{Parameters}

Fishpond A

\begin{tabular}{lcc}
\hline Represent of oxygen - saturation & $76 \%$ & $78 \%$ \\
\hline 5-day biochemical consumption of $\mathrm{O}_{2}$ at $20{ }^{\circ} \mathrm{C}$ & $1,25 \mathrm{mg} / \mathrm{l}$ & $1,30 \mathrm{mg} / \mathrm{l}$ \\
\hline Chemical oxygen demand & $4,95 \mathrm{mg} / \mathrm{l}$ & $3,00 \mathrm{mg} / \mathrm{l}$ \\
\hline Dry residue of filtered water & $36,0 \mathrm{mg} / \mathrm{l}$ & $39,0 \mathrm{mg} / \mathrm{l}$ \\
\hline $\mathrm{pH}$ & 8,3 & 7,15 \\
\hline Visible waste & $\mathrm{No}$ & $\mathrm{No}$ \\
\hline Visible color & $\mathrm{No}$ & $\mathrm{No}$ \\
\hline Noticeable odor & $\mathrm{No}$ & $\mathrm{No}$ \\
\hline Fe & $0,00 \mathrm{mg} / \mathrm{l} / \mathrm{l}$ & $0,030 \mathrm{mg} / \mathrm{l}$ \\
\hline Nitrites & $0,0015 \mathrm{mg} / \mathrm{l}$ & $0,0960 \mathrm{mg} / \mathrm{l}$ \\
\hline Nitrates & $0,00 \mathrm{mg} / \mathrm{l}$ & $0,00 \mathrm{mg} / \mathrm{l}$ \\
\hline Ammonia & $0,00 \mathrm{mg} / \mathrm{l}$ & $0,160 \mathrm{mg} / \mathrm{l}$ \\
\hline Turbidity & $1,0 \mathrm{NTU}$ & $1,0 \mathrm{NTU}$ \\
\hline Chlorides & $6,40 \mathrm{mg} / \mathrm{l}$ & $6,80 \mathrm{mg} / \mathrm{l}$ \\
\hline Total phosphorous & $0,0048 \mathrm{mg} / \mathrm{l}$ & $0,0070 \mathrm{mg} / \mathrm{l}$ \\
\hline Total nitrogen & $0,320 \mathrm{mg} / \mathrm{l}$ & $0,300 \mathrm{mg} / \mathrm{l}$ \\
\hline
\end{tabular}

Based on the physical - chemical properties of water from these two aquaculture facilities, water is classified into class II (according to the Regulation on water classification Official Journal of RM 18/99), which has allowed for fish production.
Considering the results of the fatty acid composition of the rainbow trout (Oncorhynchus mykiss Walbaum, 1792) from fishpond A and fishpond B, we`ve obtained the following results (Table 2, Figire 1)

Table 1 Fatty acid composition of rainbow trout (Oncorhynchus mykiss Walbaum, 1792) from fishpond A and fishpond B

\begin{tabular}{|c|c|c|c|c|}
\hline Lipid numbers & Name & Type & Fishpond A (\%) & Fishpond B (\%) \\
\hline C12:0 & Lauric acid & SFA & 1 & 0.098 \\
\hline C14:0 & Myristic acid & SFA & 1.330 & 2.007 \\
\hline C15:0 & Pentadecanoic acid & SFA & 0.068 & 0.102 \\
\hline C16:0 & Palmitic acid & SFA & 10.897 & 14.335 \\
\hline C17:0 & Heptadecanoic acid & SFA & 0.097 & 0.118 \\
\hline C18:0 & Stearic acid & SFA & 2.993 & 3.389 \\
\hline $\mathrm{C} 20: 0$ & Arachidic acid & SFA & 0.602 & 0.131 \\
\hline $\mathrm{C} 21: 0$ & Heneicosanoic acid & SFA & 0.128 & 0.123 \\
\hline TOTAL SFA & & & 16.155 & 20.303 \\
\hline C14:1 & Myristoleic acid & MUFA & 1 & 0.027 \\
\hline C16:1 & Palmitoleic acid & MUFA & 2.946 & 5.040 \\
\hline $\mathrm{C} 17: 1$ & Cis-10- Heptadecanoic acid & MUFA & 0.189 & 0.275 \\
\hline $\mathrm{C} 18: 1 \mathrm{n} 9 \mathrm{c}$ & Oleic acid & MUFA & 47.005 & 43.317 \\
\hline $\mathrm{C} 20: 1$ & Cis-11- Eicosenoic acid & MUFA & 2.081 & 2.657 \\
\hline $\mathrm{C} 22: 1 \mathrm{n} 9 \mathrm{c}$ & Cis - Erucid acid & MUFA & 0.937 & 0.694 \\
\hline $\mathrm{C} 24: 1$ & Nervonic acis & MUFA & 0.206 & 0.349 \\
\hline TOTAL MUFA & & & 53.364 & 52.359 \\
\hline $\mathrm{C} 18: 2 \mathrm{n} 6 \mathrm{t}$ & Linoleic acid & PUFA & 0.051 & 0.100 \\
\hline $\mathrm{C} 18: 2 \mathrm{n} 6 \mathrm{c}$ & Linoleic acid & PUFA & 19.075 & 15.962 \\
\hline C18:3 n6 & $\gamma$ - linolenic acid & PUFA & 5.061 & 3.520 \\
\hline $\mathrm{C} 20: 2 \mathrm{n} 6$ & Eicosadienoic acid & PUFA & 0.261 & 0.312 \\
\hline $\mathrm{C} 20: 3 \mathrm{n} 6$ & Eicosatrienoic acid & PUFA & 0.231 & 0.286 \\
\hline $\mathrm{C} 18: 3 \mathrm{n} 3$ & $\alpha$ - linolenic acid & PUFA & 0.919 & 0.596 \\
\hline $\mathrm{C} 20: 3 \mathrm{n} 3$ & Eicosatrienoic acid & PUFA & 0.305 & 0.301 \\
\hline $\mathrm{C} 20: 5 \mathrm{n} 3$ & Eicosapentaenoic acid & PUFA & 1.083 & 1.655 \\
\hline $\mathrm{C} 22: 6 \mathrm{n} 3$ & Docosahexaenoic acid & PUFA & 3.449 & 4.536 \\
\hline TOTAL PUFA & & & $\mathbf{3 0 . 4 3 5}$ & 27.268 \\
\hline Total UFA & & & 83.799 & 79.627 \\
\hline Total PUFA n-6 & & & 24.679 & 20.180 \\
\hline Total PUFA n-3 & & & 5.756 & 7.088 \\
\hline n-3/n-6 & & & 0.233 & 0.351 \\
\hline UFA/SFA & & & 5.187 & 3.921 \\
\hline PUFA/SFA & & & 1.883 & 1.343 \\
\hline PUFA/MUFA & & & 0.570 & 0.520 \\
\hline
\end{tabular}




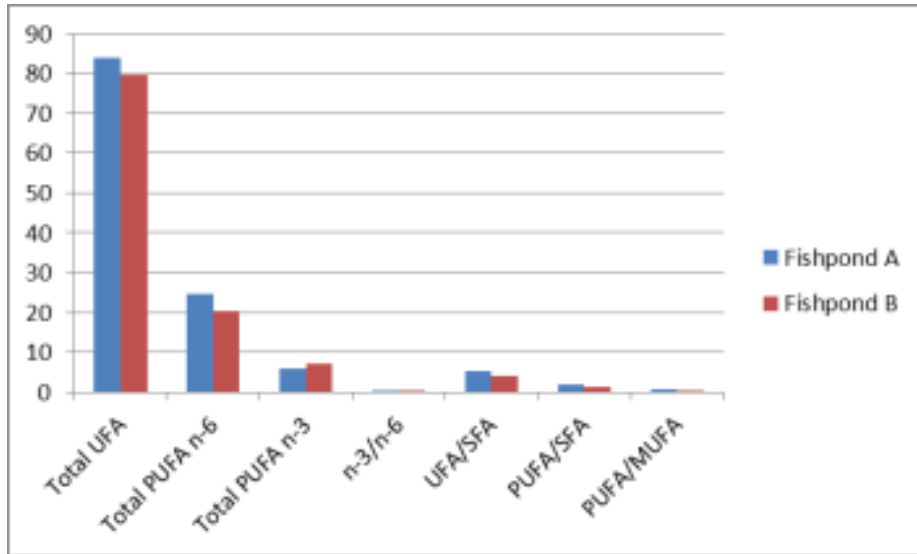

Figure 2 Comparative indicators of content and fatty acid ratio in rainbow trou (Oncorhynchus mykiss Walbaum, 1792) from fishpond A and fishpond B

Legend: UFA - unsaturated fatty acid, PUFA - polyunsaturated fatty acid, SFA - saturated fatty acid, n 3 - omega 3 fatty acid, n 6 - omega 6 fatty acid

Considering the results of the fatty acid composition of the rainbow trout from the fishpond A, it can be concluded that in total fatty acid content, saturated fatty acid (SFA) participates with $16.155 \%$. Of those, the most dominant are palmitic $(10.897 \%)$, stearic $(2.993 \%)$ and myristic $(1.330 \%)$ fatty acid. Monounsaturated fatty acids (MUFA) have the greatest participation in this fishpond, with $53.364 \%$. From those, the most dominant is oleic (47.005\%), followed by palmitoleic acid $(2.946 \%)$. Polyunsaturated fatty acids (PUFA) participate with $30.435 \%$ in total fatty acid content, from which, the most dominant are linoleic $(19.075 \%), \gamma$ - linolenic $(5.061 \%)$, docosahexaenoic DHA $(3.443 \%)$ and eicosapentaenoic EPA $(1.083 \%)$ fatty acid. N-6 (omega 6$)$ fatty acids participate with $24.679 \%$, while n-3 (omega 3) with $5.756 \%$, so the $n-3 / n$ 6 ratio is 0.233 . UFA/SFA ratio is 5.187, PUFA/SFA is 1.883 , while PUFA/MUFA is 0.570 .

Considering the results of the fatty acid composition of the rainbow trout from the fishpond $\mathrm{B}$, it can be concluded that in total fatty acid content, saturated fatty acid (SFA) participates with $20.303 \%$. Of those, the most dominant are palmitic $(14.335 \%)$, stearic $(3.389 \%)$ and myristic $(2.007 \%)$ fatty acid Monounsaturated fatty acids (MUFA) have the greatest participation in this fishpond, with $52.359 \%$. From those, the most dominant is oleic $(43.317 \%)$ and palmitoleic acid $(5.040 \%)$. Polyunsaturated fatty acids (PUFA) participate with $27.268 \%$ in total fatty acid content. From this type of acid, linoleic acid participates with the greatest percent $(15.962 \%)$, followed by $\gamma$ - linolenic $(3.520$ $\%)$, docosahexaenoic DHA $(4.536 \%)$ and eicosapentaenoic EPA $(1.655 \%)$ fatty acid. N-6 fatty acids participate with $20.180 \%$, while n-3 with $7.088 \%$, so the n$3 / \mathrm{n}-6$ ratio is 0.351 . UFA/SFA ratio is 3.921 , PUFA/SFA is 1.343 , while PUFA/MUFA is 0.520 .

Regarding the amount of SFA, the results of our research are in correlation with the findings of Mustafa and Dikel (2015) (20.74\%), but slightly lower compared to those of Blanchet et al. (2005) (26.9\%), Celik et al. (2008) (27.65\%), Danabas (2011) (26.81 - 27.93\%), Vranić et al. (2012) (29.14\%), Çagiltay et al. (2015) (22.37 - 24.6\%) and Tkaczewska et al. (2015) (19.82 - 27.90\%).

The content of MUFA in our research closely correlated with the findings of Cagiltay et al. (2015) (42.55 - 43.68\%), but higher than the results indicated by Blanchet et al. (2005) (32.5\%), Haliloglu et al. (2002) (30.81\%), Mustafa and Dikel (2015) (26.57\%), Danabas (2011) (25.3 - 31.4\%) and Vranić et al. (2012) $(33.05 \%)$

The results of PUFA's amount in our research are correlated with the data presented by Cagiltay et al. (2015) (30.86 - 32.17\%), higher than the results of Celik $\boldsymbol{e t}$ al. (2008) (9.23\%), and lower than those quoted by Blanchet $\boldsymbol{e t}$ al. (2005) (40.6\%) and Mustafa and Dikel (2015) (51.12\%).

From this statement it can be concluded that the fatty acid profile is affected by extrinsic and intrinsic factors such as genetics, development phase, environmental condition and dietary lipids.

Nutritional value of rainbow trout fillets was measured by $n-3 / n-6$ ratio. It has been suggested that this ratio is a good standard to compare the nutritional value of oils presented in meat fish. According Osman et al. (2001), n-3/n-6 ratio of $1: 1$ or $1: 1.5$ can contribute to a healthy diet in humans. In our study, the value of the $\mathrm{n}-3 / \mathrm{n}-6$ ratio for the fishpond $\mathrm{A}$ was 0.233 , while for the fishpond $\mathrm{B}$ was 0.351

According H.M.S.O. (1994) ideal n-6/n-3 ratio of fatty acids is up to 4 . Values greater than the maximum value are harmful to health and may promote cardiovascular diseases (Moreira et al., 2001). In our research $n-6 / n-3$ ratio was ranged from 4.28 for fishpond $\mathrm{A}$ to 2.84 for fishpond $\mathrm{B}$, from which it can be concluded that favorable is those from fishpond B.

According H.M.S.O. (1994) a minimum value of PUFA/SFA ratio is recommended as 0.45 , which is in correlation with our findings of 1.88 for fishpond $\mathrm{A}$ and 1.34 for fishpond $\mathrm{B}$, indicating the meat of good nutritional quality because the obtained values are higher than the minimum $(0.45)$ which is recommended for a healthy diet in humans.

According AFSSA (2003), the UFA/SFA ratio of fatty acids in fish fat is very important and its value should be over 3 . This statement is in correlation with our UFA/SFA values which for fishpond A was 5.187 and for fishpond B was 3.921.

\section{CONCLUSION}

Considering the results of the fatty acid composition of the rainbow trout from the fishpond $\mathrm{A}$ and the fishpond $\mathrm{B}$, it can be concluded that the content of the saturated fatty acids (SFA) is higher in the fishpond B $(20.303 \%)$ compared to the fishpond A (16.155\%), while the content of the monounsaturated fatty acids (MUFA) and the polyunsaturated fatty acids (PUFA) is greater in the fishpond A (MUFA - 53.364\%; PUFA - 30.435\%) compared to the fishpond B (MUFA $52.359 \%$; PUFA - 27.268\%).

In terms of the amount of n-6 fatty acids, it is higher for the fishpond A $(24.679 \%)$ compared to the fishpond B $(20.180 \%)$, while the amount of $n-3$ is greater for the fishpond B (7.088\%) compared to the fishpond A $(5.756 \%)$.

The resulting value of the relations UFA/SFA, PUFA/SFA and PUFA/MUFA is increased with the fishpond $\mathrm{A}(5.187,1.833$ and 0.570 , respectively) compared to the fishpond $\mathrm{B}(3.921,1.343$ and 0.520 , respectively), while the value of the ratio $\mathrm{n}-3 / \mathrm{n}-6$ is greater for the fishpond $\mathrm{B}(0.351)$ in comparison with the fishpond A (0.233).

In the rainbow trout from the fishpond $\mathrm{A}$, the content of the eicosapentaenoic (EPA) fatty acid is $1.083 \%$, while the one of the docosahexaenoic (DHA) fatty acid is $3.449 \%$. In the rainbow trout from the fishpond $\mathrm{B}$, the content of the EPA is $1.655 \%$, while the one of DHA is $4.536 \%$, which is higher in comparison with the fishpond A.

The variations in the fatty acid composition of the fish meat depend on many factors, but primarily on the season, the ambient temperature, the geographical location, the gender, the diet, the age of the fish, the physical and the chemical characteristics of the water, the rearing conditions, the physical activity, etc.

Overall, by a comparative analysis of the qualitative properties of the rainbow trout from the both aquaculture facilities, the ambient conditions prevailing in the aquatic environment, and the used forage mixtures for feeding fish, it can be concluded that the both aquaculture facilities are producing fish with high nutritional quality, in terms of the fatty acid composition.

\section{REFERENCES}

AFSSA (2003). Acides gras de la famille omega 3 et systeme cardiovasculaire: interet nutritionnel et allegations, AFAAA.

Aslan, S. S., Güven, K. C., Gezgin, T., Alpaslan, M. \& Tekinay, A. (2007) Comparison of fatty acid contents of wild and cultured rainbow trout Onchorhynchus mykiss in Turkey. Fisheries Science, 73(5), 1195-1198 pp http://link.springer.com/article/10.1111\%2Fj.1444-2906.2007.01452.x

Blanchet, C., Lucasa, M., Julienc, P., Morind, R., Gingrasa, S. \& Dewaillya E. (2005). Fatty acid composition of wild and farmed atlantic salmon (Salmo salar) and Rainbow Trout (Oncorhynchus mykiss). Lipids, 40, 529-531 pp http://link.springer.com/article/10.1007\%2Fs11745-005-1414-0.

Çagiltay, F., Erkan, N., Ulusoy, Ş., Selcuk, A. \& Özden, Ö. (2015). Effects of stock density on texture-colour quality and chemical composition of rainbow trout (Oncorhynchus mykiss). Iranian Journal of Fisheries Sciences 14(3), 687 698 pp. URL: http://jifro.ir/article-1-834-en.html

Celik, M., Gocke, M., Basusta, N., Kucukgulmez, A., Tasbozan, O. \& Tabakogly, S. (2008). Nutritional quality of rainbow trout (Oncorhynchus mykiss) caught from the Ataturk Dam lake in Turkey. Journal of Muscle Foods, 19 , http://onlinelibrary.wiley.com/doi/10.1111/j.17454573.2007.00099.x/abstract;jse ssionid=99374CF4EA51374E1A88A72E79876F5F.f03t02\#

Crawford, M. A. (1993). The role of essential fatty acids in neural development: implications for perinatal nutrition. American Journal of Clinical Nutrition, 57, 703-710 pp. PMID: 7682751.

Danabas, D. (2011). Fatty acids profiles of rainbow trout (Oncorhynchus mykiss, Walbaum, 1792), fed with zeolite (Clinoptilolite). The Journal of Animal \& Plant Sciences, 21(3), 561-565 pp. ISSN: 1018-7081. URL : http://www.thejaps.org.pk. Daviglus, M. L., Stamler, J., Orencia, A. J., Dyer, A. R., Liu, K., Greenland, P., Walsh, M. K, Morris, D. \& Shekelle R. B. (1997). Fish consumption and the 30year risk of fatal myocardial infarction. The new England journal of medicine, 10, 336(15), 1046-53 pp. http://dx.doi.org/10.1056/NEJM199704103361502.

Gorgun, S. \& Akpinar, M. A. (2007). Liver and muscle fatty acid composition of mature and immature rainbow trout (Oncorhynchus mykiss) fed two different diets. Biologia, Bratislava, 62(3), 351-355 pp https://www.degruyter.com/view/j/biolog.2007.62.issue-3/s11756-007-00588/s11756-007-0058-8.xml

Haliloglu, H. İ., Aras, N.M. \& Yetim, H. (2002). Comparison of Muscle Fatty Acids of Three Trout Species (Salvelinus alpinus, Salmo trutta fario, Oncorhynchus mykiss) Raised under the Same Conditions. Turkish Journal of Veterinary and Animal Sciences. 26, 1097-1102 pp. 
H.M.S.O. (1994) Nutritional aspects of cardiovascular disease (report on health and social subjects No. 46). London, HMSO.

Jankowska, B., Zakes, Z., Zmijewski, T. \& Szczepkowski, M. (2003). A comparison of selected quality features of the tissue and slaughter yield of wild and cultivated pikeperch Sander lucioperca (L.). European Food Research and Technology, 217,401-405 http://link.springer.com/article/10.1007\%2Fs00217-003-0757-5.

Moreira, A.B., Visentainer, J.V., De Souza, N.E. \& Matsushita M. (2001). Fatty acids profile and cholesterol contents of three Brazilian Brycon freshwater fishes. J Food Comp Anal. 14(6), 565-574 pp. http://www.sciencedirect.com/science/article/pii/S0889157501910257?via\%3Dih ub.

Mozaffarian, D., Bryson, C. L., Lemaitre, R. N., Burke, G. L. \& Siscovick, D. S (2005). Fish intake and risk of incident heart failure. Journal of the American College of Cardiology, 45(12), 2015-2021 pp. http://www.sciencedirect.com/science/article/pii/S0735109705007527.

Mustafa, O.Z. \& Dikel, S. (2015). Comparison of Body Compositions and Fatty Acid Profiles of Farmed and Wild Rainbow Trout (Oncorhynchus mykiss). Food Science and Technology, 3, $56 \quad-\quad 60 \quad$ pp http://www.hrpub.org/journals/article info.php?aid=2996.

Osman, H., Suriah, A.R. \& Law, E.C. (2001). Fatty acid composition and cholesterol content of selected marine fish in Malaysian water. Food Chem. 73 55-60 pp. http://www.sciencedirect.com/science/article/pii/S0308814600002776. Özoğul, Y., Özogul, F. \& Alagoz, S. (2007). Fatty acid profiles and fat contents of commercially important seawater and freshwater fish species of Turkey: A comparative study. Food Chemistry, 103, 217-223 pp http://www.sciencedirect.com/science/article/pii/S0308814606006327.

Sarma, D., Akhtar, M., Shahi, N., Ciji, A., Mahanta, P., Yengkokpam, S. \& Debnath D. (2013). Nutritional quality in terms of amino acid and fatty acid of five coldwater fish species: Implications to human health. Nation. Acad. Sci. Letters, 36: 385-391 pp. http://link.springer.com/article/10.1007\%2Fs40009-0130151-1.

Tkaczewska, J., Kulawik, P. \& Migdał, W. (2015). The quality of rainbow trout (Oncorhynchus mykiss) cultured in various Polish regions. Ann. Anim. Sci., Vol. 15, No. 2, 527-539 pp. http://dx.doi.org/\%20https://doi.org/10.2478/aoas

Vranić, D., Baltić, Ž. M., Trbović, D., Đinović-Stojanović, J., Marković, R., Petronijević, R. \& Spirić, A. (2012). Mlađ i konzumna kalifornijska pastrmka (Oncorhynchus mykiss): hemijski sastav, sadržaj holesterola i masnokiselinski sastav fileta. Tehnologija mesa 53, 1, 26-35 pp. http://scindeks.ceon.rs/Article.aspx?artid=0494-98461201026V. 